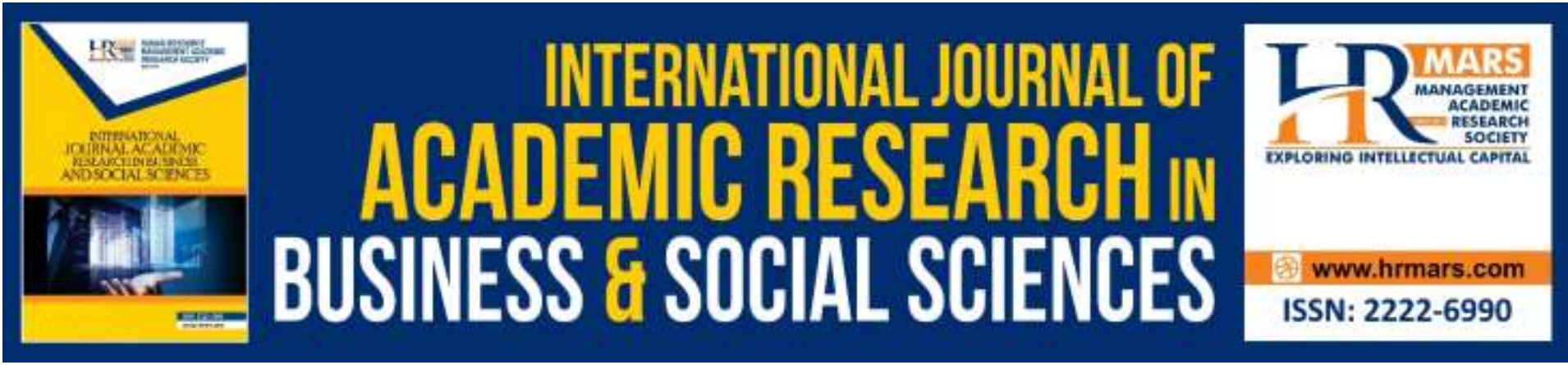

\title{
Examining Effectiveness of an Authentic Problem-based Learning Model based on Uncertainty Level and Learning Performance of Engineering Students Studying Physics
}

\author{
Loh Kah Heng, Lim You Ping, Low Khai Rol
}

To Link this Article: http://dx.doi.org/10.6007/IJARBSS/v10-i4/7157

DOI:10.6007/IJARBSS/v10-i4/7157

Received: 27 February 2020, Revised: 28 March 2020, Accepted: 07 April 2020

Published Online: 25 April 2020

In-Text Citation: (Heng et al., 2020)

To Cite this Article: Heng, L. K., Ping, L. Y., \& Rol, L. K. (2020). Examining Effectiveness of an Authentic Problembased Learning Model based on Uncertainty Level and Learning Performance of Engineering Students studying Physics. International Journal of Academic Research in Business and Social Science, 10(4), 585599.

Copyright: (C) 2020 The Author(s)

Published by Human Resource Management Academic Research Society (www.hrmars.com)

This article is published under the Creative Commons Attribution (CC BY 4.0) license. Anyone may reproduce, distribute, translate and create derivative works of this article (for both commercial and non-commercial purposes), subject to full attribution to the original publication and authors. The full terms of this license may be seen at: http://creativecommons.org/licences/by/4.0/legalcode

Vol. 10, No. 4, 2020, Pg. 585 - 599

Full Terms \& Conditions of access and use can be found at http://hrmars.com/index.php/pages/detail/publication-ethics 


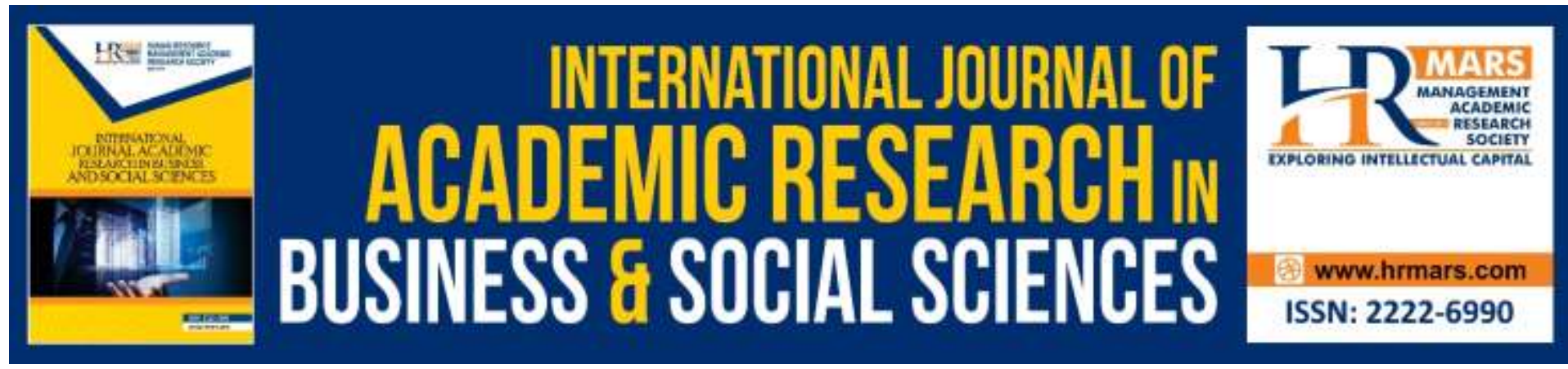

\title{
Examining Effectiveness of an Authentic Problem-based Learning Model based on Uncertainty Level and Learning Performance of Engineering Students studying Physics
}

\author{
${ }^{1}$ Loh Kah Heng, ${ }^{2}$ Lim You Ping, ${ }^{3}$ Low Khai Rol \\ ${ }^{1,2}$ School of Liberal Arts and Sciences, Faculty of Social, Science and Leisure Management, \\ Taylor's University, Malaysia, ${ }^{3}$ FairView International School, Subang, Malaysia
}

\begin{abstract}
Introducing uncertainty into instruction-based classroom has been looked into by some educators to increase students' learning in terms of problem solving skills. In Problembased learning (PBL) environment, uncertainty is naturally incorporated into the ill-structured problem which is crafted purposively to motivate and stimulate PBL learners' learning process as the natural provocation for real learning. This study adopts the quasi-experimental approach and correlational design to explore the relationship between PBL learners' uncertainty level and learning performance and the effectiveness of an authentic problembased learning (APBL) model in reducing uncertainty level. 78 Physics students from Taylor's American Degree Program in Fall 2017 semester participated in this study. A 30-item selfreporting, numerically measurable questionnaire to capture the learners' uncertainty level with regards to the cognitive, affective and physical dimension was developed. A pre-test on the uncertainty level was conducted to some students who have volunteered to fill out the questionnaire immediately after they learned the PBL scenario which served to determine whether the PBL question has incorporated uncertainty and if there is a reduce in uncertainty level after completing the PBL activities. Posttest on the uncertainty level was conducted after learners presented their solution or proposal to the problem. Learning performance scores constitutes three measures, namely learning satisfaction, learning attitude, and learning score. Learning satisfaction consists of 10-item self-reporting, numerically measurable questionnaire. The Cronbach's alphas for uncertainty construct and learning satisfaction are 0.89 and 0.92 respectively. One sample $T$ test was conducted to study the effectiveness of APBL in reducing the level of uncertainty. A Pearson's correlation coefficient between the variables were obtained. The results of zero order correlation analysis showed a strong negative correlation between uncertainty level and learning performance. One sample t-test result showed that learners' uncertainty level were significantly reduced after the APBL activities.
\end{abstract}

Keywords: Authentic Problem-based Learning, Cognitive Uncertainty, Physical Uncertainty, Affective Uncertainty, Learning Performance. 
INTERNATIONAL JOURNAL OF ACADEMIC RESEARCH IN BUSINESS AND SOCIAL SCIENCES Vol. 10, No. 4, April, 2020, E-ISSN: 2222-6990 @ 2020 HRMARS

\section{Introduction}

Uncertainty is a term used in various discipline with different interpretation. It receives a great attention in the study of decision making. A remarkable rise in interest in uncertainty in decision making has been observed in the past decades. In the education field, particularly in teaching and learning, uncertainty is not welcomed by the educators and students due to the fact that they view uncertainty as anxiety, ambiguity and confusion, particularly in the traditional teaching approach where "certainty" is the gold standard of teaching and learning outcome. However, with the current shift of education landscap from teaching to learning paradigm where the student-centered learning approach such as Problem-based learning (PBL) has been increasingly gaining its popularity, uncertainty has become an integral part of the crafting of PBL scenario particularly in the higher education. PBL has always been coined with Donald Woods of McMaster University Medical School in 1960s who was the first to use realistic medical problems to deal with his students before they were presented with any other curriculum input. This approach was then extended to other domains in various educational level, particularly in higher education. The unique feature of $P B L$ is the injection of uncertainty naturally as a source of intrinsic motivation and a stimulus to learning which appears as the natural provocations for real learning. The uncertainty in PBL is originated from the lack of knowledge due to the fact that they are not exposed to curriculum input prior to the PBL question given to them. Students are required to assess what they know and what they do not know, and they are challenged to make decision to fill the gap of knowledge uncertainty in order to construct the meaningful knowledge. This feature in the learning paradigm is very much different from the traditional approach of teaching paradigm where students and lecturers believe that the purpose of teaching and learning is the resolving of uncertainty level and the main resources to close the gap of knowledge and reduce uncertainty are the educators and textbooks. According to Lee (1998), students and lecturers in the traditional lecture system believe that the purpose of teaching and learning is the reduction of uncertainty. This is the common practice in schools, colleges and universities in Malaysia for decades. They believe that knowledge consists of right answers and learning is the memorization and reproduction of these answers.

Today's university students who have completed secondary education are highly dependent on teachers who spoon fed them with knowledge to reduce uncertainty in learning. Cynthia (2015) reported that today's learners face a difficult, uncertain and complex future. As such, universities must work to equip learners with the skills they need to confront with new challenges.

It is known that one of the unique features of PBL is to present the ill-structured real-world problems to students before they are taught with the topic or knowledge (Savery, 1995), and these problems incorporate uncertainty naturally as a source of intrinsic motivation and stimulus to their learning. Ben Johnson (2011) articulated that "Teachers need to inject a little uncertainty into their lessons every day because it engages students at the "analysis and above" levels. It forces the students to evaluate what they know and what they do not know and make a decision about what to do about it". He further describe that "one of the main goals of the educational approach known as constructivism is to prepare learners for uncertainty by helping them feel comfortable in postulating, guessing, hypothesizing, conjecturing, and testing their theories". However, Ronald A. Beghetto (2017) explains that in the traditional classroom, teachers replaced uncertainty with over-planned learning experience by providing a well-defined problem, teaching students how to solve the problem 
and leading to desired outcome. This is because teachers themselves are uncomfortable with uncertainty, they tried to avoid uncertainty, and attempt to resolve it quickly when they experience uncertainty. In his article, he proposed a shift in the conception of uncertainty by inviting uncertainty into classroom to foster the problem solving skills in students. He explained that uncertainty can be categorized into bad and good format. Bad uncertainty will lead to chaos in learning experience because it lacks proper support and structure. However, good uncertainty can be viewed as it provides opportunities for students to engage with unknowns in a well-structured environment which is supported by instructors. He also suggested teachers to try lesson-unplanning approach which could have embedded uncertainty into their lesson and students will have more opportunities to practice working through problems with various ways to achieve their learning outcome and they are more likely to take on complex problems. He also suggested to assign complex challenges to students in the classroom in order to prepare them to respond to uncertainty in a more productive manner.

Tauritz (2012) expressed an urgent need to enhance 'uncertainty competences' in children due to the fact that they are facing complex (environmental) challenges. She mentioned that young children are already confronted with knowledge uncertainty and teachers need to teach them how to cope with this uncertainty particularly in the knowledge aspect. Traditionally, teachers tried to provide instructions with clarity and efficiency aimed to prevent or eliminate ambiguity (Visser and Visser, 2004). This has indirectly shielded students from uncertainty and refrain the students from opportunity to handle uncertainty. In her research framework, she mentioned that too little or too much of uncertainty block learning, while sufficient uncertainty will motivate learning. She used PBL as an approach to develop an uncertainty action plan where students learn through facilitated problem solving. During PBL activities, students are confronted with a complex real world problem for which there is no definite answer. They worked in groups identifying what they need to learn in order to solve the problem. A plan is made to divide tasks and decide how useful information will be gathered. Facilitator should discuss the inherent uncertainty of planning. During the process students adjust their planning according to the chain of events. During problem solving process, students enhance problem solving skills, decision making, self-directed learning and collaboration skills (Hmelo-Silver, 2004). The teacher facilitates learning by providing scaffolding, modelling a positive attitude towards an uncertain, open-ended process and providing feedback (Schmidt et al. 2011). In addition to the uncertainty related to content, experienced knowledge uncertainty could also be due to procedural or task ambiguity and complexity. In other words, the instructions aren't clear enough or the learner does not (yet) have the abilities to proceed effectively (Van Merriënboer et al. 2003).

\section{Problem Statement}

Many universities encourage their faculty to adopt PBL as a student-centered approach in their academic discipline, with the rational that this approach will increase students' satisfaction and enhance their learning ability and lifelong learning skills. However, PBL create anxiety due to lack of prior learning experience and team dynamic issue as well as proper crafted problem scenario. PBL learners face high anxiety to cope with solving challenging problem in the PBL problem. A PBL session without proper crafted problem and planned session generate overload of uncertainty and anxiety which lead to unfavorable and negative learning experience. 
INTERNATIONAL JOURNAL OF ACADEMIC RESEARCH IN BUSINESS AND SOCIAL SCIENCES Vol. 10, No. 4, April, 2020, E-ISSN: 2222-6990 @ 2020 HRMARS

By adopting an authentic PBL (APBL) model with proper injection of uncertainty into well crafted illdefined real world problem and well-planned in all stages of PBL activities, anxiety due to uncertainty can be reduced and learning will then take place which can be measured through the assessment of learning performance.

\section{Purpose of the Study}

The purpose of this study is two-fold, firstly is to determine the effectiveness of APBL in reducing the uncertainty and increasing in learning satisfaction of engineering students in the APBL model and secondly to investigate the correlation between uncertainty level and learning performance of the Engineering students after attending the APBL approach for the physics course in American Degree Program at Taylor's University, Malaysia.

A set of null hypotheses and its subsidiary null hypotheses were formulated to guide the research process.

$\mathrm{H}_{\circ 1}$ : There is no statistically significant difference between initial uncertainty level and final uncertainty level of the engineering students in the APBL Model

$\mathrm{H}_{\mathrm{o1a}}$ : There is no statistically significant difference between initial uncertainty level and final uncertainty level with regards to cognitive dimension of the engineering students in the APBL Model.

$\mathrm{H}_{\mathrm{o} 1 \mathrm{~b}}$ : There is no statistically significant difference between initial uncertainty level and final uncertainty level with regards to affective dimension of the engineering students in the APBL Model.

$\mathrm{H}_{\mathrm{o} 1 \mathrm{c}}$ : There is no statistically significant difference between initial uncertainty level and final uncertainty level with regards to physical dimension of the engineering students in the APBL Model

$\mathrm{H}_{\mathrm{o2}}$ : There is no statistically significant difference between initial learning satisfaction level and final learning satisfaction level of the engineering students in the APBL Model.

$\mathrm{H}_{03}$ : There is no statistically significant negative correlation exists between uncertainty and learning performance of engineering students in APBL Model.

$\mathrm{H}_{\text {о3a }}$ : There is no statistically significant negative correlation exists between uncertainty and learning satisfaction of engineering students in APBL Model.

$\mathrm{Ho}_{3 \mathrm{~b}}$ : There is no statistically significant negative correlation exists between uncertainty and learning attitude of engineering students in APBL Model.

$\mathrm{H}_{03 c}$ : There is no statistically significant negative correlation exists between uncertainty and learning score of engineering students in APBL Model.

\section{Research Framework}

An Authentic Problem-based learning (APBL) is adopted in this study. The APBL approach is adapted from the RP's “one-day, One-Problem" PBL model (G. O'Grady et al., 2002) and build around Wilson Problem-solving model (1999). The APBL approach is conducted on Saturday from 8 am to 5 pm to avoid clashing in students' time-table. 
INTERNATIONAL JOURNAL OF ACADEMIC RESEARCH IN BUSINESS AND SOCIAL SCIENCES

Vol. 10, No. 4, April, 2020, E-ISSN: 2222-6990 @ 2020 HRMARS

In this APBL model, students undertaking Physics course will be given a "real world" problem which land them to the following "TIPS" (Wee, 2004) stages:

- Trigger their learning, students will encounter high uncertainty level and curiosity when they receive a problem which is beyond their existing knowledge to tackle it.

- Inquire and information seeking to clarify and identify the problem for uncertainty resolution by stating the problem statement (During Meeting 1 for uncertainty resolution).

- Propose ideas to manage the problem after seeking more information to fill the knowledge gap for uncertainty resolution (during Meeting 2 for further uncertainty resolution)

- Seek and acquire new knowledge alongside with solving the problem (During meeting 3 to compile the acquired knowledge for further uncertainty resolution).

These stages will be taking place in at least 3 meetings, where each meeting serves to reduce uncertainty, as shown in figure 1: The Wilson's Problem solving model.

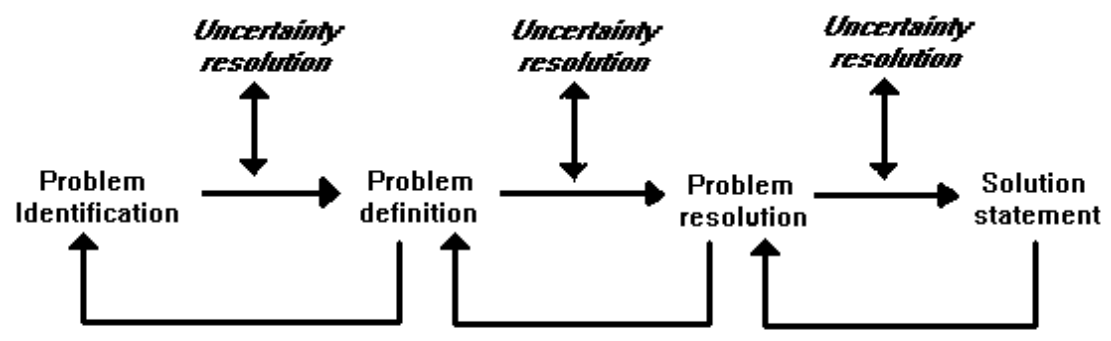

Figure 1. Wilson's Problem Solving model 
INTERNATIONAL JOURNAL OF ACADEMIC RESEARCH IN BUSINESS AND SOCIAL SCIENCES Vol. 10, No. 4, April, 2020, E-ISSN: 2222-6990 @ 2020 HRMARS

The research framework adopted from Wilson Problem Solving Model for this study in shown in Figure 2.

\begin{tabular}{|c|c|c|c|c|c|}
\hline Meeting 1- & \multicolumn{2}{|l|}{$\begin{array}{l}\text { Knowledge } \\
\text { Acquisition, } \\
\text { Reduce uncertainty }\end{array}$} & \multicolumn{2}{|l|}{$\begin{array}{l}\text { Knowledge } \\
\text { Acquisition, } \\
\text { Reduce uncertainty }\end{array}$} & \multirow{2}{*}{ 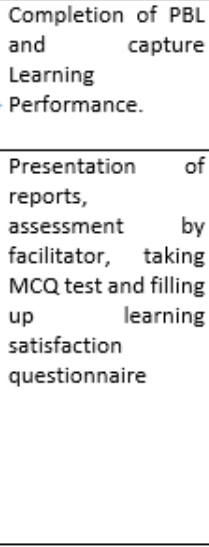 } \\
\hline $\begin{array}{l}\text { Problem Presentation } \\
\text { and identification. } \\
\text { - Students form groups } \\
\text { to identify existing } \\
\text { knowledge, unknown } \\
\text { knowledge and } \\
\text { knowledge gap, } \\
\text { - Each student will be } \\
\text { assigned role to } \\
\text { perform tasks. } \\
\text { - Some students } \\
\text { answer uncertainty } \\
\text { questionnaire }\end{array}$ & $\begin{array}{l}\text { All students acquire } \\
\text { knowledge to } \\
\text { perform task along } \\
\text { with reducing } \\
\text { uncertainty. }\end{array}$ & $\begin{array}{l}\text { Gather newly acquired } \\
\text { knowledge from all } \\
\text { members in the group } \\
\text { - to make sense of } \\
\text { the problem, } \\
\text { - narrow the } \\
\text { knowledge gap and } \\
\text { propose further } \\
\text { ideas to manage } \\
\text { the problem }\end{array}$ & $\begin{array}{l}\text { All students continue } \\
\text { acquire knowledge to } \\
\text { perform task along } \\
\text { with reducing } \\
\text { uncertainty. }\end{array}$ & \begin{tabular}{|l|} 
- \\
knowing \\
gap bedge by \\
compiling all \\
the \\
information \\
acquired and \\
present the \\
final solution. \\
- students \\
answer \\
uncertainty \\
questionnaire \\
\end{tabular} & \\
\hline $\begin{array}{l}\text { Initial level of Total } \\
\text { Uncertainty }\end{array}$ & \multicolumn{2}{|l|}{$\mathrm{H}_{01}$} & $\begin{array}{l}\text { Final Level of Total } \\
\text { Uncertainty }\end{array}$ & & \\
\hline $\begin{array}{l}\text { Cognitive } \\
\text { Dimension }\end{array}$ & \multirow{3}{*}{\multicolumn{2}{|c|}{$\mathrm{H}_{01 \mathrm{~s}}, \mathrm{H}_{01 \mathrm{~b}} \mathrm{H}_{01 \mathrm{c}}$}} & $\begin{array}{l}\text { Cognitive } \\
\text { Dimension }\end{array}$ & & \\
\hline $\begin{array}{l}\text { Affective } \\
\text { Dimension }\end{array}$ & & & $\begin{array}{l}\text { Affective } \\
\text { Dimension }\end{array}$ & & $\begin{array}{l}\text { Learning } \\
\text { Performance }\end{array}$ \\
\hline \begin{tabular}{|l|} 
Physical \\
Dimension \\
\end{tabular} & & & $\begin{array}{l}\text { Physical } \\
\text { Dimension }\end{array}$ & & $\begin{array}{l}\text { Learning } \\
\text { satisfaction }\end{array}$ \\
\hline $\begin{array}{l}\text { Initial level of learning } \\
\text { satisfaction }\end{array}$ & \multicolumn{4}{|l|}{$\mathrm{H}_{02}$} & \begin{tabular}{|l} 
Attitude \\
Learning Score
\end{tabular} \\
\hline
\end{tabular}

Figure 2: Research Framework for this study

Meeting 1 allows the engineering students to form groups and to be presented with ill-structured problem to trigger learning and curiosity, and stating problem statement and identify existing knowledge as well as knowledge gap. Individual member is assigned with specific task and proceed to information seeking process. Meeting 2 allows students to gather information and newly acquired knowledge from all members in the group to make sense of the problem, narrow the knowledge gap and propose further ideas to manage the problem. Individual member continues to seek information to solve the problem. In meeting 3, the knowledge gap is closed by compiling all the information acquired and present the final solution. Students are required to submit their report at the end of the day, any time before mid-night (24:00) of the day.

Most of the previous research efforts in problem-based learning did not look into the aspect of uncertainty in the PBL which stimulate learning process and how the uncertainty level related to the learning performance in the PBL environment. This research aims to explore the effectiveness of APBL in reducing the uncertainty level and relationship between the uncertainty level and learning performance of engineering students. 
INTERNATIONAL JOURNAL OF ACADEMIC RESEARCH IN BUSINESS AND SOCIAL SCIENCES Vol. 10, No. 4, April, 2020, E-ISSN: 2222-6990 @ 2020 HRMARS

\section{Definitions}

Uncertainty

In the context of this study, uncertainty construct is characterized by behavior in terms of cognitive dimension, affective dimension and physical dimension. Uncertainty is reduced with regards to positive attitude, more focus and understanding of domain knowledge, which is associated with reduce in their affective state in terms of feeling and emotion such as apprehensive, anxiety, confusion and frustration, and physical state of hesitation and perturbation in performing learning task.

Uncertainty level is operationalized as the cognitive state of uncertainty with regards to clearly focused thoughts, associated with the affective state of uncertainty in terms of confidence and positive attitude and physical state of uncertainty level through increased information seeking activities to fill the gap between information required and information processed. The level of uncertainty is measured using a 30-items, self-report measure in a five-point Likert-response format design to assess the uncertainty in cognitive dimension, affective dimension and physical dimension in the pretest questionnaires and posttest questionnaires while they performed a learning task in the problem-based learning environment.

\section{Learning Performance}

Learning performance composes three constructs, learning satisfaction and learning attitude are subjective measure and learning score is the objective measure. It is defined as the learning satisfaction with regards to the benefits of information seeking process through construction and made sense of the information gathered and knowledge acquisition, and application of knowledge gained to perform the learning task. It is expressed as a function of these indicators, with weightage assigned to the respective indicators as shown in the figure 3.

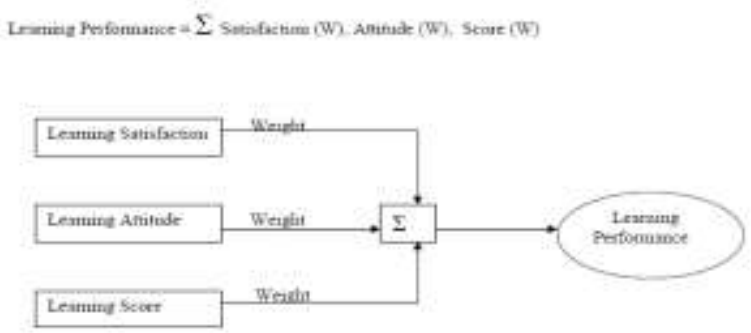

Figure 3. Expression of Learning Performance

Learning performance is operationalised as student's motivation with regards to the benefits of information seeking in helping learning, and knowledge acquisition with regards to knowledge retention and application of knowledge to solve problem that exhibit a positive attitude towards working out the solution in a team effort to achieve the goal. Learning satisfaction is measured using 10 -items of self-report measure rated on a scale varying from one being "strongly disagree to five being "strongly agree" on the learner's satisfaction adapted from the usefulness instrument developed and tested by Davis (1989). Learning attitude is measured using 8-items instrument to evaluate student's attitude by facilitator during the whole PBL activities inclusive the assessment for the report presentation of the learning task on a scale varying from one being "unsatisfactory" to five 
INTERNATIONAL JOURNAL OF ACADEMIC RESEARCH IN BUSINESS AND SOCIAL SCIENCES

Vol. 10, No. 4, April, 2020, E-ISSN: 2222-6990 @ 2020 HRMARS

being "exceptionally satisfactory", together with the marks assigned to the report of the solution of PBL learning task.

Learning score is the assessment on a test sheet which consists of 15 multiple choice questions designed for the topics on course unit conducted in PBL.

\section{Methodology}

This study adopts both quasi-experimental and correlational research design with 78 engineering students enroll to Physics courses participated in the study. A total of 39 students volunteered to fill out the questionnaire on uncertainty level which consists of 30 items of uncertainty constructs prior to performing the APBL tasks. These students came from all APBL subgroup but were not required to write down their names. As all the students have not had the prior knowledge on the scenario and were not taught on the topic beforehand, they were presumed to have similar initial uncertainty level. The mean initial level of uncertainty in all the three dimensions were calculated and compare with the final uncertainty level which aims to study the change in uncertainty level after the APBL tasks. This will allow researchers to study the effectiveness of the APBL classroom in reducing the level of uncertainty. The questionnaire consists of 30 items of uncertainty constructs and 10 items on satisfaction of learning experience in 5 points Likert scale. All participants are post tested on their uncertainty level and satisfaction in learning experience about the learning task at the end of the APBL process after they have submitted their report or solution.

\section{Participants}

This research recruited 78 university students major in engineering who registered to undertake Physics course in the Fall 2017 semester in the American Degree Transfer Program at Taylor's University to participate in this study. The facilitator spent 20 minutes to brief the APBL scenario to the students and started to divide all students in groups of five to six students. The groups of students were then given sometime to discuss and formulating their problem statement. Some students were requested to fill out the questionnaire on uncertainty level on a volunteering basis without recording their names in order to capture the initial uncertainty level after learning the APBL scenario. All participants were given the questionnaire on uncertainty and learning satisfaction to fill out after they completed the APBL tasks and submitted together with the APBL report. The participants will be tested on the domain related to APBL problem with Multiple Choice Questions one week after the APBL session.

\section{Instruments}

The variables in this study are students' uncertainty level and Learning performance. A carefully crafted "ill-structured" problem scenario that triggers the learning activity is given to all participants, with 20 minutes perusal time. The pretest of uncertainty level is administered to PBL learners volunteering to fill out the uncertainty questionnaire. This questionnaire consists of 30 items of uncertainty construct which record their thinking, feeling and action in terms of cognitive dimension, affective dimension and physical dimension and 10 items on satisfaction of learning experience in 5 points Likert scale. A posttest instrument which is similar to pretest instrument is administered to all students at the end of the APBL process. The variables can be computed using SPSS to determine the mean score of the uncertainty level in each item attributed to the uncertainty construct and learning 
INTERNATIONAL JOURNAL OF ACADEMIC RESEARCH IN BUSINESS AND SOCIAL SCIENCES Vol. 10, No. 4, April, 2020, E-ISSN: 2222-6990 C 2020 HRMARS

performance. The 1 sample $\mathrm{T}$ test was performed on the Uncertainty construct and learning satisfaction construct while Pearson's Correlational analysis was carried out on uncertainty and learning performance variables which served to reject and fail to reject the null hypotheses.

\section{Results and Findings}

The objective of this study is to investigate the effectiveness of APBL in reducing students' uncertainty level with regards to its three associated dimension, namely cognitive, affective and physical dimensions, as well as the relationship between APBL learners' uncertainty level and learning performance. In order to examine whether these objectives are achieved, it is imperative to test all the null hypotheses and the associated subsidiary hypotheses.

\section{Testing of Null Hypothesis $\mathrm{H}_{01}$}

$\mathrm{H}_{\mathrm{o1}}$ : There is no statistically significant difference between initial uncertainty level and final uncertainty level of the engineering students in the APBL Model

$\mathrm{H}_{\mathrm{o1a}}$ : There is no statistically significant difference between initial uncertainty level and final uncertainty level with regards to cognitive dimension of the engineering students in the APBL Model.

$\mathrm{H}_{\mathrm{o1b}}$ : There is no statistically significant difference between initial uncertainty level and final uncertainty level with regards to affective dimension of the engineering students in the APBL Model.

$\mathrm{H}_{\mathrm{o1c}}$ : There is no statistically significant difference between initial uncertainty level and final uncertainty level with regards to physical dimension of the engineering students in the APBL Model

The mean of total initial level of uncertainty (computed from the average of all the three dimension of uncertainty) and the initial level of uncertainty in cognitive, affective and physical dimension were computed from the descriptive analysis. A one sample t-test on the final level of uncertainty and its associated dimension were performed to study if there is a statistical significant difference from the initial level of uncertainty. The results derived from the one sample-T test was summarized in Table 1. 
INTERNATIONAL JOURNAL OF ACADEMIC RESEARCH IN BUSINESS AND SOCIAL SCIENCES Vol. 10, No. 4, April, 2020, E-ISSN: 2222-6990 @ 2020 HRMARS

Table 1: Results from one sample t-test

\begin{tabular}{|c|c|c|}
\hline Null Hypotheses (1 sample t test) & Results & Alternative Hypotheses \\
\hline $\begin{array}{l}\mathrm{H}_{\mathrm{ol}}: \text { There is no statistically } \\
\text { significant difference between initial } \\
\text { uncertainty level and final } \\
\text { uncertainty level of the engineering } \\
\text { students in the APBL Model. }\end{array}$ & $\begin{array}{l}\text { The difference in final } \\
\text { uncertainty level of the } \\
\text { sample }(n=78, M=2.28, S D \\
=0.49) \text { and the initial } \\
\text { uncertainty level }(2.80) \text { were } \\
\text { statistically significant } \\
t(77)=-6.846, p=0.000 \\
\text { Reject } H_{01} \text { in favor of } H_{1}\end{array}$ & $\begin{array}{l}\mathrm{H}_{1}: \text { There is statistically } \\
\text { significant difference } \\
\text { between initial uncertainty } \\
\text { level and final uncertainty } \\
\text { level of the engineering } \\
\text { students in the APBL } \\
\text { Model. }\end{array}$ \\
\hline $\begin{array}{l}\mathrm{H}_{\mathrm{ola}} \text { : There is no statistically } \\
\text { significant difference between initial } \\
\text { uncertainty level and final } \\
\text { uncertainty level with regards to } \\
\text { cognitive dimension of the } \\
\text { engineering students in the APBL } \\
\text { Model. }\end{array}$ & $\begin{array}{l}\text { The difference in final } \\
\text { uncertainty level of the } \\
\text { sample with regards to } \\
\text { cognitive dimension ( } n=78 \text {, } \\
M=2.41, S D=0.54 \text { ) and the } \\
\text { initial uncertainty level }(2.70 \text { ) } \\
\text { were statistically significant } \\
t(77)=-4.716, p=0.000 \\
\text { Reject } \mathrm{H}_{01 a} \text { in favor of } \mathrm{H}_{1 \mathrm{a}}\end{array}$ & $\begin{array}{l}\mathrm{H}_{1 \mathrm{a}} \text { : There is statistically } \\
\text { significant difference } \\
\text { between initial uncertainty } \\
\text { level and final uncertainty } \\
\text { level with regards to } \\
\text { cognitive dimension of the } \\
\text { engineering students in } \\
\text { the APBL Model. }\end{array}$ \\
\hline $\begin{array}{l}\mathrm{H}_{\mathrm{o} \mathrm{b}}: \text { There is no statistically } \\
\text { significant difference between initial } \\
\text { uncertainty level and final } \\
\text { uncertainty level with regards } t \\
\text { affective dimension of the } \\
\text { engineering students in the APBL } \\
\text { Model. }\end{array}$ & $\begin{array}{l}\text { The difference in final } \\
\text { uncertainty level of the } \\
\text { sample with regards to } \\
\text { affective dimension ( } n=78 \text {, } \\
M=2.27, S D=0.48 \text { ) and the } \\
\text { initial uncertainty level (2.69) } \\
\text { were statistically significant } \\
t(77)=-7.035, p=0.000 \\
\text { Reject } H_{01 b} \text { in favor of } H_{1 b}\end{array}$ & $\begin{array}{l}\mathrm{H}_{1 \mathrm{~b}} \text { : There is statistically } \\
\text { significant difference } \\
\text { between initial uncertainty } \\
\text { level and final uncertainty } \\
\text { level with regards to } \\
\text { affective dimension of the } \\
\text { engineering students in } \\
\text { the APBL Model. }\end{array}$ \\
\hline $\begin{array}{l}\mathrm{H}_{\mathrm{o} 1 \mathrm{c}} \text { : There is no statistically } \\
\text { significant difference between initial } \\
\text { uncertainty level and final } \\
\text { uncertainty level with regards to } \\
\text { physical dimension of the } \\
\text { engineering students in the APBL } \\
\text { Model. }\end{array}$ & $\begin{array}{l}\text { The difference in final } \\
\text { uncertainty level of the } \\
\text { sample with regards to } \\
\text { cognitive dimension ( } n=78 \text {, } \\
M=2.36, S D=0.45 \text { ) and the } \\
\text { initial uncertainty level }(2.72) \\
\text { were statistically significant } \\
t(77)=-7.82, p=0.000 \\
\text { Reject } \boldsymbol{H}_{01 c} \text { in favor of } \boldsymbol{H}_{1 c}\end{array}$ & $\begin{array}{l}\mathrm{H}_{1 c} \text { : There is statistically } \\
\text { significant difference } \\
\text { between initial uncertainty } \\
\text { level and final uncertainty } \\
\text { level with regards to } \\
\text { physical dimension of the } \\
\text { engineering students in } \\
\text { the APBL Model. }\end{array}$ \\
\hline
\end{tabular}

\section{Testing of Hypothesis $\mathrm{H}_{02}$}

$\mathrm{H}_{\mathrm{o} 2}$ : There is no statistically significant difference between initial learning satisfaction level and final learning satisfaction level of the engineering students in the APBL Model

The mean of total initial level of learning satisfaction of the engineering student was computed from the descriptive analysis. A one sample t-test on the final level of learning satisfaction of the engineering student was performed to study if there is a statistical significant difference from the initial level of learning satisfaction. The results derived from the one sample-T test showed that the difference in final level learning satisfaction of the sample $(n=78, M=3.97, S D=0.043)$ and the initial 
INTERNATIONAL JOURNAL OF ACADEMIC RESEARCH IN BUSINESS AND SOCIAL SCIENCES Vol. 10, No. 4, April, 2020, E-ISSN: 2222-6990 C 2020 HRMARS

level learning satisfaction (3.74) was statistically significant, $\mathbf{t}(77)=5.44, \mathbf{p}=0.000$. Thus, the second null hypothesis was rejected in favor of its alternative hypothesis.

Hence, There is a statistically significant difference between initial learning satisfaction level and final learning satisfaction level of the engineering students in the APBL Model

\section{Testing of Hypothesis $\mathrm{H}_{03}$}

$\mathrm{H}_{03}$ : There is no statistically significant negative correlation exists between uncertainty and learning performance of engineering students in the APBL Model.

$\mathrm{H}_{\text {о3a }}$ : There is no statistically significant negative correlation exists between uncertainty and learning satisfaction of engineering students in the APBL Model.

$\mathrm{Ho}_{3 \mathrm{~b}}$ : There is no statistically significant negative correlation exists between uncertainty and learning attitude of engineering students in the APBL Model.

$\mathrm{H}_{03 c}$ : There is no statistically significant negative correlation exists between uncertainty and learning score of engineering students in the APBL Model.

A Pearson product-moment correlation was computed to assess correlation between uncertainty and learning performance of all students after APBL session. The statistical analysis revealed that these variables were, as predicted, negatively related and that the correlation was statistically significant $(r$ $=-0.19, \mathrm{n}=78, \mathrm{p}<0.05$, one-tailed). Thus, null hypothesis $\mathrm{H}_{02}$ was rejected in favour of its alternative hypothesis. It follows that there is a statistically significant, but weak negative correlation between uncertainty and learning performance in APBL environment. This statistical analysis revealed that lower uncertainty level corresponds to higher learning performance. The results derived from Pearson product-moment correlation analysis were summarized in Table 2.

Table 2: Results from Analysis of Pearson product-moment correlation

\begin{tabular}{|c|c|c|}
\hline Null Hypotheses (Pearson's r ) & Results & Alternative Hypotheses \\
\hline $\begin{array}{l}\mathrm{H}_{03} \text { : There is no statistically significant } \\
\text { negative correlation exists between } \\
\text { uncertainty and learning performance of } \\
\text { engineering students in the APBL Model. }\end{array}$ & $\begin{array}{l}\mathrm{r}=-0.19, \mathrm{n}=78, \mathrm{p}<0.05 \text {, one- } \\
\text { tailed } \\
\mathrm{H}_{03} \text { was rejected in favor of } \mathrm{H}_{2}\end{array}$ & $\begin{array}{l}\mathrm{H}_{3} \text { : There is statistically significant } \\
\text { negative correlation exists between } \\
\text { uncertainty and learning performance } \\
\text { of engineering students in the APBL } \\
\text { Model. }\end{array}$ \\
\hline $\begin{array}{l}\mathrm{H}_{\text {оза }} \text { : There is no statistically significant } \\
\text { negative correlation exists between } \\
\text { uncertainty and learning satisfaction of } \\
\text { engineering students in the APBL Model. }\end{array}$ & $\begin{array}{l}r=-0.306, n=78, p<0.05 \text { one- } \\
\text { tailed } \\
H_{03 a} \text { was rejected in favor of } H_{3 a}\end{array}$ & $\begin{array}{l}\mathrm{H}_{3 a} \text { : There is statistically significant } \\
\text { negative correlation exists between } \\
\text { uncertainty and learning satisfaction } \\
\text { of engineering students in the APBL } \\
\text { Model. }\end{array}$ \\
\hline $\begin{array}{l}\mathrm{Ho}_{3 \mathrm{~b}} \text { : There is no statistically significant } \\
\text { negative correlation exists between } \\
\text { uncertainty and learning attitude of } \\
\text { engineering students in the APBL Model. }\end{array}$ & $\begin{array}{l}r=-0.213, n=78, p<0.05 \text {, one- } \\
\text { tailed } \\
H_{03 b} \text { was rejected in favor of } H_{3 b}\end{array}$ & $\begin{array}{l}\mathrm{H}_{3 \mathrm{~b}} \text { : There is statistically significant } \\
\text { negative correlation exists between } \\
\text { uncertainty and learning attitude of } \\
\text { engineering students in the APBL } \\
\text { Model. }\end{array}$ \\
\hline $\begin{array}{l}\mathrm{H}_{03 \mathrm{c}} \text { : There is no statistically significant } \\
\text { negative correlation exists between } \\
\text { uncertainty and learning score of } \\
\text { engineering students in the APBL Model. }\end{array}$ & $\begin{array}{l}r=.148, n=78, p>0.05 \text {, one- } \\
\text { tailed } \\
\text { Fail to reject } H_{03 c}\end{array}$ & \\
\hline
\end{tabular}


INTERNATIONAL JOURNAL OF ACADEMIC RESEARCH IN BUSINESS AND SOCIAL SCIENCES Vol. 10, No. 4, April, 2020, E-ISSN: 2222-6990 @ 2020 HRMARS

\section{Testing of $\mathrm{H}_{03} \mathrm{a}$}

$\mathrm{H}_{\text {оза }}$ : There is no statistically significant negative correlation exists between uncertainty and learning satisfaction of engineering students in the APBL Model..

A Pearson product-moment correlation coefficient was computed to assess correlation between uncertainty and learning satisfaction of all students after APBL session. There was statistically significant negative correlation between the two variables $(r=-0.306, n=78, p<0.05$ one-tailed). Thus, null hypothesis $\mathrm{H}_{\text {o3a }}$ was rejected in favour of its alternative hypothesis. Overall, there is a moderate, statistically significant negative correlation exists between uncertainty and learning satisfaction. This statistical analysis revealed that lower uncertainty level corresponds to higher learning satisfaction.

\section{Testing of Hypothesis $\mathrm{H}_{03 b}$}

$\mathrm{Ho}_{3 \mathrm{~b}}$ : There is no statistically significant negative correlation exists between uncertainty and learning attitude of engineering students in the APBL Model.

A Pearson product-moment correlation was computed to assess correlation between uncertainty and learning attitude of all after APBL session. There was a statistically significant negative correlation between the two variables ( $r=-0.213, n=78, p<0.05$, one-tailed). Thus, null hypothesis $\mathrm{H}_{\text {о3b }}$ was rejected in favor of its alternative hypothesis, which stated that there is a statistically significant but weak negative correlation exists between uncertainty and learning attitude in PBL environment. Overall, this statistical analysis revealed that lower uncertainty level corresponds to higher learning attitude.

\section{Testing of Hypothesis $\mathrm{H}_{03 c}$}

$\mathrm{H}_{03 \mathrm{c}}$ : There is no statistically significant negative correlation exists between uncertainty and learning score of engineering students in the APBL Model.

A Pearson product-moment correlation coefficient was computed to assess the correlation between the uncertainty and learning score of all students after a PBL session. There was no statistically significant negative correlation between the two variables $(r=.148, n=78, p>0.05$. Thus, this statistical analysis has failed to reject the null hypothesis $\mathrm{H}_{3 c}$. Overall, there is no statistically significant negative correlation exists between uncertainty level and learning score. Instead, the finding has indicated that uncertainty is positively correlated to the learning scores, which exhibit an unanticipated result (Learning score was obtained after some time lapse). The explanation to this unanticipated result will be discussed in next section.

\section{Discussion}

Traditional lecture approach treated teaching and learning as purposefully reducing the uncertainty of students. This approach may undermine the process of learning and incapacitates student inquisitiveness and initiative. Students studying in traditional approach students always treated uncertainty as a source of anxiety, rather than a natural provocation for learning. However, APBL incorporates uncertainty naturally as a source of intrinsic motivation and a stimulus to learning. In APBL, facilitators present the scenarios of the learning experience so that students can discover the principle for themselves. APBL students will be stimulated by cognitive dissonance when they encounter an ill-structured problem. The associated uncertainty acts as a catalyst which provokes 
real learning. They will begin to seek for information to fill the gaps between what they know in their existing knowledge base and what they do not know. This activity accompanies the appearance of reorganisation, stability, and progressive development or learning (Germana \& Lancaster, 1995). In this study, the high level of uncertainty that students demonstrated at the beginning has indicated the incorporation of uncertainty in the learning tasks, and the level of uncertainty have reduced after seeking the information to fill the gap. Thus, the uncertainty level was negatively correlated to the learning satisfaction, learning attitude and learning performance. However, the low effect size of positive correlation between uncertainty level and learning score illustrate that multiple-choice questions was the inappropriate testing instrument used in PBL evaluation.

The contradictory positive correlation between uncertainty level and learning scores was really unanticipated. It is known that learning scores were the marks obtained by the students during the examination on the topics related to the APBL problems. This examination was administered one week later after the PBL activity. It was in the forms of multiple-choice questions which was the preferred format of evaluation in traditional lecturing approach. Apparently, this format of evaluation was not suitable for APBL because APBL strategy stresses on critical thinking and has a potential to structure knowledge so that acquisition and recall are optimised. Moreover, APBL students develop self-directed learning skills, which motivate them to better express the structured knowledge that they have acquired through APBL activity.

Findings from the research indicated that preferred assessment method used in the traditional lecture approach did not show evidence of negative correlation between learning as measured by the assessment method and uncertainty level. This result led to the implication that the evaluation method of learning process in APBL must stress on continuous assessment on affective and attitudinal aspect as well as their understanding rather than multiple choice questions at the end of APBL session. Structured short-answer questions could be a better alternative to the APBL assessment as APBL stresses on critical thinking and has a potential to structure knowledge which optimise the knowledge acquisition and retention.

\section{Conclusion}

One sample T-test provided evidence of the effectiveness of APBL in lowering the uncertainties and increasing in learning satisfaction level while Pearson's Product Moment correlation coefficient shows the relationship and strength of association between uncertainty and learning performance and its associated subsidiary constructs in this study.

Results from one sample T test indicates that the APBL has effectively reduced students' uncertainty level with regards to its three associated dimension, namely cognitive, affective and physical dimensions, as indicated in the table1. It also showed that the engineering students' learning satisfaction has increased after completed the APBL activities.

The Product Moment correlation coefficient analysis revealed that there was a statistically significant negative correlation between learning satisfaction, learning attitude and learning performance and the total uncertainty of the students. However, a contradictory positive correlation between uncertainty level and learning scores was observed. This correlation was opposite to the anticipated negative correlation between uncertainty and learning score. Instead, a statistically significant positive correlation between uncertainty and learning score was found. 
INTERNATIONAL JOURNAL OF ACADEMIC RESEARCH IN BUSINESS AND SOCIAL SCIENCES

Vol. 10, No. 4, April, 2020, E-ISSN: 2222-6990 @ 2020 HRMARS

\section{References}

Beghetto, R. A. (2017). Inviting uncertainty into the classroom. Educational Leadership, 75, 20 - 25.

Cynthia, L. S. (2015). The futures of learning 3: What kind of pedagogies for the 21st century? Education, Research and Foresight, Working paper, 15

Davis, F. D. (1989). Perceived usefulness, perceived ease of use and user acceptance of information technology. MIS Q., 13: 319-340. DOI: 10.2307/249008

Hmelo-Silver, C. E. (2004) “Problem-based learning: What and How Do Students Learn?" Educational Psychology Review, 16(3):235-266.

Huettel, S. A., Song, A. W., McCarthy, G. (2005). Decisions under uncertainty: probabilistic context influences activation of prefrontal and parietal cortices. J. Neurosci. 25, 3304331110.1523/JNEUROSCI.5070-04.2005 [PubMed] [CrossRef] [Google Scholar]

Johnson, B. (2011). EDUTOPIA. Helping Students Deal with Uncertainty in the Classroom.

Lee, V. S. (1998). The uses of uncertainty in the college classroom. Essays on Teaching Excellence, 12(1). Fort Collins, CO: POD Network in Higher Education.

Savery, J. R., \& Duffy, T. M. (1995). Problem-based learning: An instructional model and its constructivist framework. In Wilson, B. (eds.), Constructivist learning environments: Case studies in instructional design (pp. 135-148). Englewood Cliffs: Educational Technology Publications.

Schmidt, G., Rotgans, J., and Yew, E. (2011) "The process of problem-based learning: what works and why". Medical Education, 45(8):792-806.

Tauritz, R. (2012). How to handle knowledge uncertainty? Learning and teaching in times of accelerating change. In: Learning for Sustainability in times of accelerating change. Wageningen: Wageningen Academic Publishers.

Van Asselt, M. (2000) Perspectives on Uncertainty and Risk. The Prima Approach to Decision Support. Dordrecht: Kluwer Academic Publishers.

Visser, J., and Visser, Y. L. (2004) “Ambiguity, cognition, learning, teaching, and design”. TechTrends, 48(1):40-43. Boston: Springer.

Wee, K. N. L. (2004). Jump Start Authentic Problem Based Learning. Singapore: Prentice Hall Pearson Education South Asia Pte. Ltd.

Wee, K. N., Kek, Y. C., Silva, G., and Seah, T. H. (2000). Tried \& tested: issues \& implications for educators in problem-based learning: relearning from the learners" perspective. Paper presented at the 2nd Asia Pacific conference in Problem-based Learning organised by Temasek Polytechnic, Singapore.

Wilson, T. D. (1999). Model in information behavior research. Journal of Documentation, 55(3): 249270. 